\title{
An Analysis of the Complex Model of Motivation in Retaining and Motivating Employees
}

\author{
Promise Zvavahera \\ National University of Science and Technology \\ P.O. Box AC 939 Ascot., Cnr. Gwanda Road, Cecil Avenue \\ Bulawayo, Zimbabwe
}

E-mail: promisezvavahera59@gmail.com

Tel: 263-773-471-703 or 263-4-706-515

Received: April 10, 2015 Accepted: April 28, 2015 Published: May 7, 2015

doi:10.5296/bmh.v3i1.7416 URL: http://dx.doi.org/10.5296/bmh.v3i1.7416

\begin{abstract}
This paper seeks to critique the elements of the complex model of motivation which was developed with the aim of applying it in organisations with the view of motivating, retaining and improving on productivity and service delivery. The model is premised on the internal and external factors that impact on employees' performance. The Complex Model of Motivation is deemed to be comprehensive in its application. It is noted that employees are plagued with various problems which negate on their performance. It is therefore, recommended that if this Model is applied it could go a long way in addressing most of the problems raised by employees at the workplace. This Model suggests a holistic approach involving internal and external factors that impact on the total work environment. The model is significant in that it identifies promising areas in which organisations can improve so as to provide conducive working environments.
\end{abstract}

Keywords: Human capital management, organisations, incentives, motivation, retention, productivity 


\section{Introduction}

This study was aimed at critiquing the existing models of motivation and then presenting a proposed model for the Zimbabwean context. A model represents assumptions about relationship of players or variables in the real life situation. The fact that there are many theories of motivation shows the complexity of the subject. According to Cole (2004), the origin of staff motivation and retention started with Taylor in the $19^{\text {th }}$ century when he came up with the Scientific Management Approach. The Complex Model of Motivation which was developed by the researcher is assumed to be comprehensive in its approach and application. It further asserts that improved productivity is only possible for organisations which are able to motivate and retain their staff. It is critical to encompass internal and external factors when coming up with a motivating and retention strategy for an organisation.

Motivation is complex since organisations engage people from different backgrounds such as married and unmarried, female and male, old and young, with different traits and aspirations. Managers must therefore, find what motivate different workers before directing their efforts to fulfill their needs and complete organisational goals (Gannon, 1979). Mukokoma (2008), states that what is difficult is to come up with a strategy which can fully address issues affecting employees at the workplace. She further asserts that there is no specific motivation recipe that will work across all organisations. Even though managers realize that employees need to be motivated, it must be noted that there are a lot of employees who are not motivated in organisations. The motivation problem is multi-faceted and this poses serious problems to both employers and employees especially the Human Resources Specialist, hence the need for a critical study. Most managers blanket motivation strategies without customising it to individual and organizational differences (Mukokoma, 2008).

\section{Literature Review}

Taylor in his Scientific Management Approach was concerned with the economic man, whereby earnings were more important than anything else. In his experiment that was carried out at Bethlehem Steel Company in 1908, employees were paid according to output. Since other important aspects that impact on employee motivation and retention were left out, there was despondency at the plant (Statt, 1994). Riley (2012) states that Taylor's approach had many weaknesses since employees were different and need different approaches. It was therefore, concluded that monetary awards alone were not enough to motivate and retain employees at the workplaces.

The view that employees are motivated by money only was refuted by later studies (Cole 2009; Maslow, 1950; Vroom, 1964). What is critical is to make sure that organisations create enabling environments for their employees (Baron \& Greenberg, 2003; Werner, 2007). Cole (2009) avers that organisations should create work environments and policies which are sensitive to the needs of their employees so as to get maximum output. When organisational policies and systems are acceptable to employees, motivation, retention and productivity are likely to improve. Management should recruit and develop staff that is committed to the achievement of organisational goals and objectives. Fair working conditions and good salaries are critical for the proper management of human capital in organisations. 
Maslow (1950) also came up with the Hierarchy of Needs Theory. According to Maslow, employees' needs are arranged in an array whereby they are satisfied systematically. According to Maslow, shelter is a basic need. However, in Zimbabwe having your own accommodation is a high level need. For instance, the majority of employees in Zimbabwe live in rented accommodation which is very expensive. In Zimbabwe, Professors might be regarded as having achieved their ego yet some of them do not have the basic need, which is accommodation. When management is taking this root, they need to take cognisance of various forces at play such as cultural values and norms, economic, technological and many others which negate on the performance of employees. This theory failed to fully address the motivational needs of all employees and make then stay in their employment. Employees are ambitious beings and they always strive to achieve more in life. It can be argued that Maslow's hierarchy of needs is rigid and difficult to be applied in real life situations. Some of these needs can also be achieved simultaneously.

McGregor's Theory X and Y are likened to the scientific management type of approach. According to Theory $\mathrm{X}$ employees generally dislike work and to this end need to be coerced. He indicates that people by nature dislike work and can avoid responsibility whenever they have the opportunity to do so. On the other hand, Theory Y expresses that employees enjoy work and they prefer to exercise self-control and self-discipline. Cole (2009) avers that such types of people require minimum supervision to achieve set goals and objectives. This theory emphasises that if employees are afforded the opportunity to control their work, they are likely to satisfy their needs towards self actualisation. This theory does not also fully address the motivational requirements of employees at the workplace.

Vroom’s Expectancy Theory compressed Maslow's Hierarchy of Needs Theory by coming up with two variables which are valence and expectancy. Valence is about anticipated satisfaction for the individual. On the other hand, expectancy assumes that a particular act will be followed by a predictable outcome. He postulates that people are influenced by the expected results of their actions. This theory does not cover the whole spectrum of variables that make employees happy and committed. The work environment is complex.

The Human Relations School (1933) discovered that since employees are social beings, they normally do not respond as groups and cannot have predetermined motivational levels and behaviours. There are a lot of issues that need to be considered when motivating employees. Even though employees got higher wages during Taylor's time, industrial unrests increased. This then implies that employees are complex and a holistic approach in addressing their needs is the most desirable way to go. The implications of Taylor's theory for managing behaviour at work are that, employees need to be empowered so that they make important decisions and feel to be part and parcel of the organisation. Since employees are different and complex beings, the application of both extrinsic and intrinsic motivators are important. Employees come to work for various reasons. According to Cole (2009), researchers involved in motivation theories made assumptions about the motives for behaviour, which they had observed or recorded. Taylor used observation only as the data collection instrument during his experiments. The employees were not given the opportunity to indicate on what motivated them. The complex model tries to address workers as individuals with different traits and 
aspirations in life.

\subsection{The Complexity in Motivating and Retaining Employees}

People are unique thus understanding their needs and attempting to address them individually is difficult. When people grow or change in status, their needs also change. It has also been identified that there are some people who do not even know what they want. The problem is to a larger extent compounded by organisational politics. Another problem is that intrinsic motivation is intangible. This means that it is inherent in an individual. Extrinsic motivators are ingredients which drive an employee to act in a certain manner. Such factors include supervision, promotion and money. Labour laws in most countries deal with hygiene factors such as acceptable working environments and salaries. When working conditions are bad, the employer can be taken to court.

\section{Complex Model of Motivation}

The complex model of motivation is an attempt to improve on Taylor's model which was developed in the $19^{\text {th }}$ century and since then a lot has changed in the working relationships. Complex Model states that the issue of motivation is complex in that it needs a holistic approach (Cole, 2004). Peters (1960) came up with "Chaos Theory” in trying to address organisational challenges. As this sounds applicable, no matter how chaotic the situation could be solutions need to be found. People are complex and varied. They respond to a variety of managerial strategies and are affected positively and negatively by different tasks and different work groups. On the other hand, Schein (1988) states that employers and employees must respect one another, and build mutual relationships which are productive for both parties. A variety of issues affect employees and productivity at the workplace. Employees expectations vary from time to time and managers need to be aware of this and act accordingly. The model of this study concentrates on how employees can be motivated intrinsically and extrinsically. The external environment is added to the already complex situation as exhibited by figure 1 which illustrates the complex model of motivation. People are unique thus understanding their needs and attempting to address as individuals. 
COMPLEX MODEL OF MOTIVATION

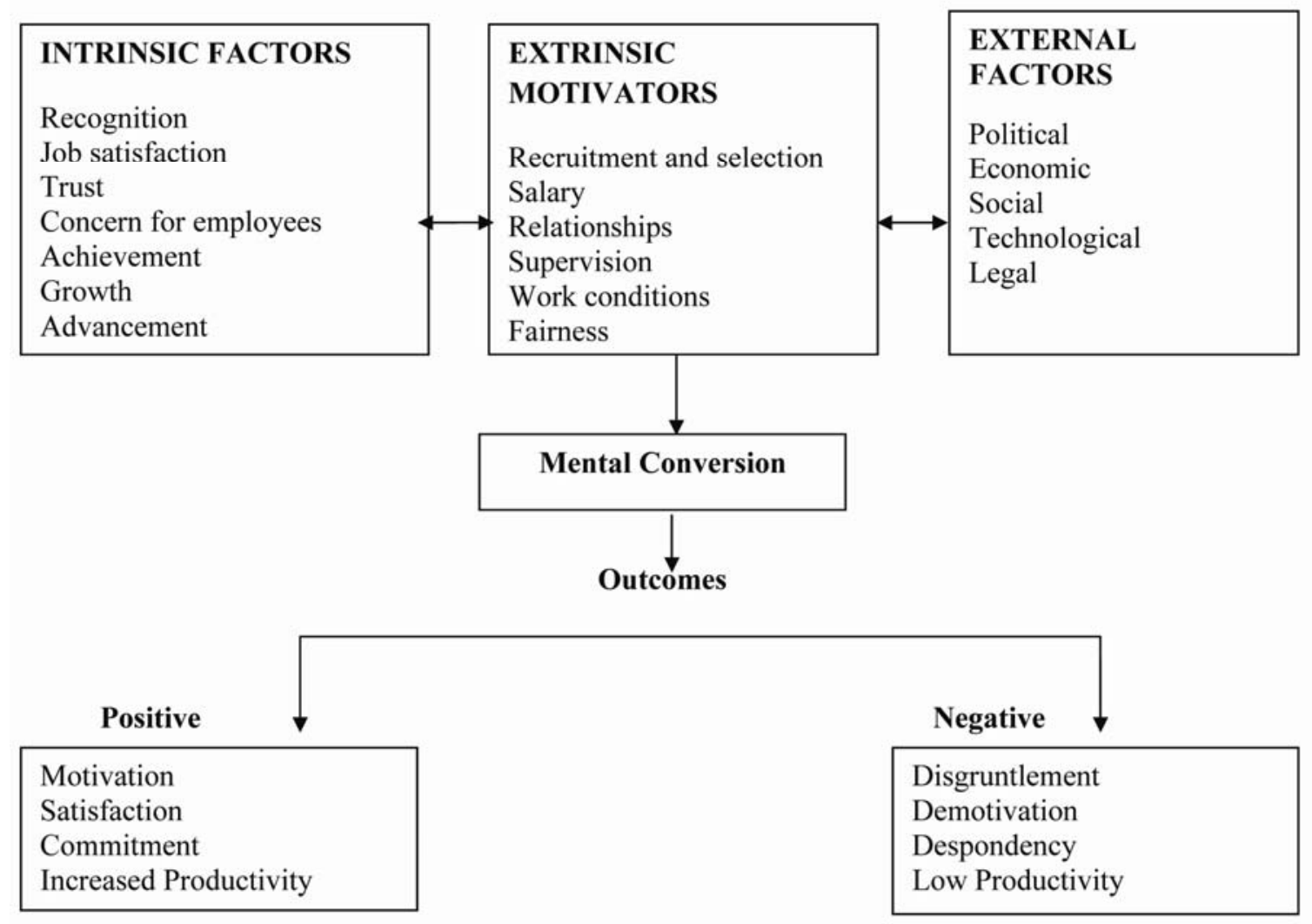

Figure 1. The complex model of motivation

\subsection{Intrinsic Factors}

Individuals have the desire and pleasure to do something they have an interest in. Intrinsic motivation is self-fulfilling. It is not directed towards a reward or gain. This implies that not all employees go to work for money. Others go to work just because they enjoy it. This is similar to Mac Gregor's Theory Y (1960), whereby some employees just enjoy work as much as they enjoy play. Intrinsic motivation to a greater extent includes recognition, job satisfaction, achievement, trust and cconcern for employees.

\subsubsection{Recognition}

Recognition brings in the 'we feeling' to all the workers resulting in intrinsically motivating them. If employees feel that they are part and parcel of the organisation, they can do everything possible to protect their interests and the organisation's interests as well. All employees need to be treated with respect. A pat on the back to some employees is more than a salary increase. What is lacking in some organisations is to publicly acknowledge and appreciate good work done by employees. Individual efforts need to be recognised and rewarded accordingly. According to Lumley et al. (2011), job satisfaction is having good feelings about one's total work environment. Individuals feel committed and motivated when their welfare is taken care of. If employees feel good about working for an organisation, this 
is likely to increase their satisfaction and commitment which translates to improved productivity. Employees fit well in organisations which are forward looking.

\subsubsection{Trust}

Employers should cultivate the trust and confidence in employees by allowing them to participate and be innovative. Supervisors play a crucial role in the perceptions employees form about the organisation's supportiveness and the extent to which it can be trusted to look after their needs (Coetzee, 2005). It is believed that employers inspire loyalty, trust and admiration in groups which are forward looking.

\subsubsection{Concern for Employees}

Coetzee (2005) acknowledges that employees have to be regarded as people not as factors of production as was initially advocated by Taylor (1908). Employees are critical and strategic resources in organisations but some employers pay less attention to the needs of their employees. They are the resource that can make or break organisations. Employers are therefore, called upon to provide job security as far as possible, train and develop employees, be flexible to accommodate employee issues, be open and honest and assist employees to have life outside work environment. Organisations should strive to motivate and retain their employees. Organisations' practices and the trust worthiness of management should spur employees' commitment to them. Employees reciprocate by rendering their loyalty and commitment to the organisation. If all the above issues are given enough attention, there is likely to be a satisfied, motivated, committed workforce, which will increase productivity. Most organisations are interested in results and these can be achieved by motivated staff.

\subsubsection{Achievement, Growth and Advancement}

Achievement is an accomplishment through hard work. In this respect, the employee feels a sense of accomplishment if praised for the good work done and that is great motivation in itself. Personal growth for employees is very important and most employees like that and they really appreciate. Growth can be attained through having greater responsibility in the organisation through promotion, training and advancement.

Promotion and advancement systems in an organisation play an important role in motivating and retaining employees. The procedures for the above have to be clear and fair to all employees in terms of applicability. Promotion and advancement have to be linked to performance.

\subsection{Extrinsic Factors}

Extrinsic motivation is external to an employee and fades quickly since it is not from within. Salary is the remuneration paid periodically by an employer to an employee. The amount is frequently specified in an employment contract. Salary is extrinsic since it is external to the individual employee. Salary encompasses all that is paid to an employee for some work done. Organisations must make sure that salaries paid to their employees are adequate. If employees are paid less than what their counterparts are paid, there is likely to be despondency and resentment at the workplace. In a study that was carried out by Spector 
(2008), it was established that earning a higher salary does not necessarily mean improved employee performance. It can also be regarded as behaviour directed towards an outcome. This factor contradicts the intrinsic factor. This is normally driven by outside forces. Examples of extrinsic motivators are salaries in that once they are used up, the other need rises for some more. It is not from within the individual and it lasts for a short period. Below are some extrinsic factors.

\subsubsection{Recruitment and Selection}

Within the external and internal systems, there are issues which affect recruitment and selection. Recruitment and selection procedures need to be transparent and adhered to. The labour laws also have an impact on issues to do with discrimination when recruitment is being done.

\subsubsection{Relationships}

The relationship between the manager and the managed has to be sound. Bad relationships can be counter-productive since employees will not be happy. Building working networks in organisations goes a long way in achieving the targets. Because of technological advancements employees can now work from home and even be more productivity than coming to work every day. Human resources practitioners have also found it naïve for employees work to for eight hours even the volume of work is very low. What is advocated for in this knowledge based economies and organisations are to know what they want to achieve. If organisations and governments fail to be productive and offer quality service, their relevance will remain questionable as they are answerable to the general public.

\subsubsection{Work Conditions}

Employees draw their inspiration and satisfaction from supportive work environments. If working conditions are not addressed, employees are likely to develop withdrawal behaviours which are counter-productive. It is therefore, critical to come up with good working and living conditions for organisation's employees so that they produce superior results. Satisfactory results can never be achieved with a disgruntled workforce.

\subsubsection{Fairness}

When employees feel that they are treated equally, they are motivated and are likely to stay with the organisation for quite a long time. According to Coetzee (2005), fairness is subjective. He further asserts that fairness deals with policies that are non-biased. These should provide competitive benefits and develop employees by providing opportunities for growth and fairness in terms of creating a fair and just work environment.

\subsection{External Environment}

The external environment includes political, economic social, technology and legal. Organisational environments are made more complex with the external environment in which most cases, organisations don't have control over. 


\subsubsection{Political Factors}

The only way to remain relevant is to adapt to any changes such as regulatory frameworks and other requirements that impact on businesses such as consumer pressure groups. Politics is a broad term with various meanings from literature. The following definitions are given. Bronston and Allen (1977), define politics as an end that is not sanctioned by the organisation. Cherrington (1989) states that politics is individualistic in nature, as it is self-fulfilling. Politics is about fulfilling individuals' aspirations at the expense of the majority. Pfeffer (1981) notes that organisations are political entities. He further illustrates that for one to understand organisational politics, one has to understand governments. Shenge (2004) defines organisational politics as behaviour strategically designed to maximize the self-interests of individuals. Organisational politics is individualistic in nature and tends to benefit a few individuals. Problems stem from sharing of resources in a biased manner. This essentially takes place when managers take vital decisions that are not based on rational considerations, for instance sending an employee on training based on an employee's personal relationship with the manager rather than on need or merit (Shenge, 2004). He further points out that politics in organisations affect employees' performance and productivity. Literature shows that the organisational policies need to always recognize the need for eliminating intense politics in workplaces so as to boost workers' satisfaction and productivity. Shenge (2004) acknowledges that organisational politics is a disease which needs to be well managed to optimise performance in organisations. According to Shenge (2004), organisational politics is usually negative and affects morale and motivation. Some of the problems of organisational politics include: victimization, partiality, favouritism and nepotism which also lead to other problems such as absenteeism, coming late, turnover intention, perceived poor working conditions and dissatisfaction. Blunt and Johns (1992) note that political systems in Africa depend largely on patronage. Most people want to get access to politicians in order to influence policy decisions and to get supply of resources and protection against extreme politics. Such politics has to be earned through loyalty and careful network building (Blunt \& Johns, 1992).

\subsubsection{Economic Factors}

Performances of economies affect the operations of organisations and the welfare of employees. For instance, the global economic meltdown affected many organisations throughout the world. The issue of salaries and downsizing are on the cards in most organisations. These measures are leading to a demotivated staff resulting in salary reductions, loss of jobs and poor working conditions. Organisations are working on cost-cutting measures in order to survive.

\subsubsection{Social Factors}

It is critical that organisations create free time for their employees so that they can have fun and relax from their daily schedules which affect the physical and mental health of employees. According to the Magazine of Human Resources (2003), conflicting responsibilities and balance have become an important issue with employees. Lockwood (2003) states that companies which motivate and retain their employees are likely to increase productivity. 
Properly balancing work and family tend to have higher productivity.

\subsubsection{Technological Factors}

Many activities in most organisations are now technologically driven and the inadequacy of this important resource can affect the operations of the organisation. This can also be taken as a source of competitive advantage. Failure to serve customers on time due to poor use of technology can lead to frustration, customer withdrawal and loss of business.

\subsubsection{Legal Factors}

Legal issues are those matters that can be contested in the court of law. Organisations should strive to avoid labour disputes with their employees as these are costly for both parties. Most labour legislations favour employees hence organisations lose most of the contested cases. Organisations must make sure that their codes of conduct are in line with the Labour legislation which governs all employment related issues. For instance, in Zimbabwe if the code of conduct is not in line with the Labour Act, this will be deemed null and void. These laws affect the human resource function in areas such as employment opportunities, compensation and benefits, leave days, labour relations and occupational safety and health at the workplace.

\subsection{Mental Conversion}

Conversion means something which has changed in nature, form or function in terms of the mental processes that take place in employees. Employees observe the internal and external environments and how they affect them. This process brings about attitudes and feelings which are exhibited through performance and decisions. The mental conversion process can create positive or negative attitudes and feelings towards the organisation and attainment of organisational goals.

\subsection{Outcomes}

Outcomes from employees can be positive or negative depending on how employees perceive the working environment and other factors. An outcome can be defined as the end-result of a process. Outcomes can be positive or negative as shown in the model. If organisations fail to do the minimum to motivate and retain workers, the result is the destruction of the organisation. If organizations put together the minimum requirements, employees are likely to be motivated and improve on productivity. Having put together all the above factors, the outcomes could motivate the workforce, satisfy workforce and increase productivity. This means that the organisation can achieve the desired results at minimum cost.

\subsubsection{Positive Outcomes}

\subsubsection{Motivation}

Positive outcomes from the mental conversion are always good for the organisation as this would be a sign of a committed work force. Cole (2009) defines motivation as a process in which people choose between alternative forms of behaviour in order to achieve personal goals. Motivation can also be defined as the driver to action. Goals sought by individuals can 
be tangible such as money, promotion or intangible such as self-esteem. This form of motivation is inherent in an individual employee. A motivated workforce is perceived to be a productive workforce. There are many theories of motivation and these have been explained elsewhere.

\subsubsection{Satisfaction}

This is defined as an act of fulfilling an obligation. This is a feeling of having achieved one's desires. Satisfaction is within an individual employee and is not external. For instance, an employee can be satisfied by performing a task and achieving the desired results. This type of employee is worried not only economic gains but also with achievement. This can also be compared to Maslow's self-actualisation theory.

\subsubsection{Commitment}

Employee commitment can be defined as the desire in which individuals exhibit positive behaviour and direction towards achievement of organisational goals and objectives (Scholls, 1981). Reilly and Chatman (1986) define it as the bond which exists between the organisation and its employees. Coetzee (2005) says that organizations need to face the future with certainty to maintain and upgrade their organisation's ability to use human resources effectively and efficiently. He further elaborates that modern organisations are facing challenges which include among others, maintaining employees' commitment in the current competitive business environment.

\subsubsection{Increased Productivity}

Productivity can be the most important measure of any organisation's performance. High productivity is a sign of a motivated and committed workforce involved. In organisations workforce productivity could be measured in terms of meeting targets with minimum costs compared to competitors.

\subsubsection{Negative Outcomes}

\subsubsection{Disgruntlement}

A disgruntled workforce is dangerous to the organisation. When workers are not happy they have the potential to destroy the organisation. They can steal from the organisation, destroy equipment and even destroy the organisation's customer base.

\subsubsection{Demotivation}

A demotivated workforce can lead to reduced productivity and profitability of the organisation. Employees who are not happy can do what they are paid for but cannot go an extra mile in meeting customer needs. Employees are likely to do the minimum to get a day's pay and prevent retrenchment.

\subsubsection{Despondency}

When work conditions are not favourable, employees lose the enthusiasm to work for the organisation. Despondency may lead to hopelessness in employees. Despondency at the 
workplaces can lead to strikes and stay-aways. During Taylor's time (1908), there were series of strikes at the workplaces because employees were treated as machines who could not think or react. Despondency at the workplace can lead to work stoppages which eventually harm the profitability and viability of the organisation.

\subsubsection{Low Productivity}

When employees' morale is low, productivity and profitability of the organisation are negatively affected. A disgruntled workforce cannot put all its energies and resources towards achieving organisational goals. When employees are disgruntled, they can do the minimum to get paid only.

\section{Conclusion}

Zimbabwean workers are plagued with various challenges that demoralise them and force them to seek transfers and resignations. This paper proposes that if all the elements of the Complex Model of Motivation are applied in Zimbabwean organisations, most of the problems raised by employees will be solved. This Model has the potential to help many other organisations even beyond the borders of Zimbabwe since most human resources issue could be similar.The major challenges of poor state of infrastructure and obsolete equipment, limited career and professional development opportunities and generally poor conditions of service can be minimised if this model in applied in full. The Model suggests a holistic approach involving internal and external factors that impact on the total work environment. Human issues at the work place are varied, complex and a holistic approach is critical. Today's work environment is complex due to globalisation and the ever changing labour laws. Young employees are hopping from one job to other looking for accommodative environments with good salaries. The issue of motivation and retention is central to all organisations. The study is significant in that it identifies promising areas on which the government can work on to provide the conditions of service so that they can successfully participate in the national and global economy. Organisations are required to develop tailor-made strategies for their organisations. Failure to do so leads to staff being demotivated, which can lead to poor service delivery and poor results.

\section{References}

Baron, A. R., \& Greenberg, J. (2003). Behaviour in organisations: Understanding and managing the human side of work. Englewood Cliffs, NJ: Prentice-Hall.

Blunt, P., \& Johns, M. L. (1992). Managing Organisations in Africa. Walter de Gruyter. http://dx.doi.org/10.1515/9783110850031

Bronston, T. M., \& Allen, R. W. (1977). Toward a Definition of Organisational Politics. Academy of Management Review, 2.

Coetzee, M. (2005). Employee Commitment, Chapter 5. University of Pretoria.

Cole, G. A. (2004). Management Theory and Practice (6th ed.). Thomson.

Cole, G. A. (2009). Personnel and Human Resources Management (5th ed.). Book Power. 


\section{Macrothink}

Business and Management Horizons

ISSN 2326-0297

2015, Vol. 3, No. 1

Gannon, L. (1985). Earned helplessness versus reactance: The effects of sex-role stereotypy. Sex Roles, 12(7/8). http://dx.doi.org/10.1007/BF00287872

Lockheed, M., \& Verspoor, A. (1991). Improving Primary Education in Developing Countries. Oxford University Press, World Bank.

Lumley, E. J., Coetzee, M., Tladinyane, R., \& Ferreira, N. (2011). Exploring the Job Satisfaction and Organisational Commitment of Employees in the Information Technology. Enxion.

Mukokoma, M. (2008). Motivation Dilemma: A case of Uganda. African Research and Documentation Centre. Uganda Martyrs University. http://dx.doi.org/10.4314/mtafiti.v20i1.38364

Peters, T. (1991). Thriving on Chaos. A Handbook for Management Revolution. Harper Collins Publishers.

Pfeffer, J. (1981). Power in Organisations. Cambridge: Ballinger Publishing Company.

Riley, J. (2012). Motivation Theory-Taylor. [Online] Available: http://tutor2u.net/business/people/motivation_theory_taylor.asp

Satt, D. A. (1994). Psychology and the World of Work. London: Macmillan Press (Ltd).

Scholl, R. W. (1981). Differentiating Organisational Commitment from expectancy as a motivating force. Academy of Management Review, 6(4), 589-599.

Shenge, N. A. (2007). Perceiving Organisational Politics and getting satisfied or dissatisfied with job. African Journal for Psychological Study of Social, (1), 91-99.

\section{Copyright Disclaimer}

Copyright for this article is retained by the author(s), with first publication rights granted to the journal.

This is an open-access article distributed under the terms and conditions of the Creative Commons Attribution license (http://creativecommons.org/licenses/by/3.0/). 